\title{
PERUBAHAN RUMUSAN PASAL 1 AYAT (2) UUD 1945, IMPLIKASI DAN IMPLEMENTASINYA DALAM KETATANEGARAAN
}

\author{
Oleh : \\ Anwar Cengkeng*
}

\begin{abstract}
Problem identified in this research are as mentioned in the following. First, how is sovereignty conception according to article 1 sub article (2) of 1945 Constitution? Second, how is implication of change in article 1 sub article (2) of 1945 Constitution state body that had mandate to perform the sovereignty? And third, how is implementation of sovereignty 1 sub article (2) of 1945 Constitution to the Indonesia constitution system? This research included in the category of normative law research and descriptive analysis in nature. The result of the dissertation are as mentioned in the following, First, the sovereignty of conception adopted in the 1945 constitution is sovereignty of the God, state, peoples, and law. Second, the change of formulation of article 1 sub article (2) 1945 constituion has implications on state body of sovereignty performance. Third, in general conception of sovereignty, according to article 1 sub article (2) 1945 constitution, implementation have in Indonesia constitution system, good in arrangement of paintbrush institute state in 1945 constitution, and also in so many act, except in its bearing with authority of DPR and DPD.
\end{abstract}

Kata Kunci: kedaulatan, demokrasi, dan the rule of law.

\section{PENDAHULUAN}

Salah satu kelemahan UUD 1945 (naskah asli) adalah kurangnya dasar-dasar checks and balances. Kurangnya dasar-dasar checks and balances dapat di lihat dalam rumusan Pasal 1 ayat (2) UUD 1945 (sebelum perubahan), bahwa "Kedaulatan adalah di tangan rakyat, dan dilakukan sepenuhnya oleh Majelis Permusyawaratan Rakyat". Berdasarkan rumusan Pasal 1 ayat (2) UUD 1945 (asli), Sri Soemantri M, ${ }^{1}$ berpendapat bahwa MPR merupakan satu-satunya alat perlengkapan negara yang melaksanakan kedaulatan rakyat. ${ }^{2}$ Berdasarkan rumusan itu,

\footnotetext{
* Dosen Fak. Hukum Univ. Widyagama Malang.

' Sri Soemantri M, UUD dan Ketetapan MPR sebagai produk $M P R$, pidato pengukuhan pada penerimaan jabatan Guru Besar Tetap dalam mata kuliah HTN pada Fakultas Hukum UNPAD, sabtu, 21 Februari 1987, hlm. 8.
}

ditafsirkan bahwa seolah-olah kedaulatan yang berada di tangan rakyat beralih sepenuhnya kepada MPR untuk bertindak sebagai penyelenggara negara tertinggi, padahal kedaulatan itu tetap di tangan rakyat, MPR hanya sebagai pelaksana kedaulatan rakyat. Dalam kaitan ini, Laica Marzuki mengemukakan bahwa "MPR adalah mandataris rakyat, bukan penerima delegasi. Dalam mandatum, mandant (atau mandator) tidak kehilangan kewenangan. MPR selaku mandataris, bertindak untuk dan atas nama

2 Hal ini berbeda dengan sistem yang dianut oleh Konstitusi RIS 1949 dan UDS 1950. Dalam Pasal 1 ayat (2) Konstitusi RIS 1949, kedaulatan dilakukan oleh Pemerintah bersama-sama dengan DPR dan senat. Adapun kedaulatan rakyat dalam Pasal 1 ayat (2) UUDS 1950 dilakukan oleh Pemerintah bersamasama dengan DPR. 
rakyat selaku mandant (atau mandator). ${ }^{3}$ Kekuasaan MPR yang sangat besar ini, menempatkannya sebagai lembaga tertinggi negara dan sebagai puncak dari struktur ketatanegaraan kita. Secara teoretis, kekuasaan MPR yang sangat besar ini menyebabkan MPR tidak mudah dikontrol oleh lembaga negara yang ada, bahkan sering kali UUD 1945 diingkari sehingga terkesan bahwa kekuasaan MPR berada di atas UUD $1945 .{ }^{4}$

Pada perubahan ketiga UUD 1945, rumusan Pasal 1 ayat (2) UUD 1945 berubah menjadi "Kedaulatan berada di tangan rakyat dan dilaksanakan menurut UUD”. Berdasarkan rumusan tentang kedaulatan yang baru tersebut, MPR tidak lagi sebagai pelaksana tunggal atau pelaksana sepenuhnya kedaulatan rakyat, pelaksana kedaulatan rakyat sepenuhnya diserahkan pada mekanisme konstitusi.

Menyangkut siapa yang berdaulat (berkuasa) dalam suatu negara, dalam ilmu kenegaraan dikenal adanya beberapa teori atau ajaran, yaitu: Teori Kedaulatan Tuhan; Teori Kedaulatan Raja; Teori Kedaulatan Negara; Teori Kedaulatan Rakyat; dan Teori

${ }^{3}$ Laica Marzuki, dalam Soewoto Mulyosudarmo, Pembaharuan Ketatanegaraan Melalui Perubahan Konstitusi, Asosiasi Pengajar HTN \& HAN Jawa Timur- In-TRANS, Malang, 2004, hlm. 278-279.

${ }^{4}$ Dari perspektif ilmu politik, sistem politik yang belaku mungkin saja seorang Presiden mengontrol anggota MPR melalui undang-undang dan mekanisme pengisian keanggotaan MPR. sebagaimana yang terjadi pada era pemerintahan Soekarno dan Soeharto.

5 Perubahan Pertama UUD 1945 diputuskan dalam Rapat Paripurna MPR RI ke-12 tanggal 19 Oktober 1999 pada Sidang Umum MPR RI; Perubahan Kedua UUD 1945 diputuskan dalam Rapat Paripurna MPR RI tanggal 18 Agustus 2000 pada Sidang Tahunan MPR RI; Perubahan Ketiga UUD 1945 diputuskan dalam Rapat Paripurna MPR RI ke7 tanggal 9 November 2001 pada Sidang Tahunan MPR RI; Perubahan Keempat UUD 1945 diputuskan dalam Rapat Paripurna MPR RI ke-6 tanggal 10 Agustus 2002 pada Sidang Tahunan MPR RI.
Kedaulatan Hukum. ${ }^{6}$

Berdasarkan pengertian dan batasan dalam penelitian ini, rumusan Pasal 1 ayat (2) UUD 1945, menurut Soewoto Mulyosudarmo, rumusan Pasal 1 ayat (2) UUD 1945 yang baru sekaligus menampung prinsip ketatanegaraan, yaitu kedaulatan hukum, kedaulatan rakyat dan kedaulatan parlemen. " Kedaulatan berada di tangan rakyat" menunjukkan bahwa UUD 1945 menganut paham kedaulatan rakyat, sedangkan pada kalimat "dilaksanakan menurut UUD" menunjukkan kedaulatan hukum. Paham kedaulatan hukum juga dapat disimpulkan dari rumusan Pasal 1 ayat (3) UUD 1945, bahwa "Negara Indonesia adalah Negara hukum". Demikian pula jikalau kita perhatikan alinea ketiga dan keempat pembukaan UUD 1945, di situ ada pengakuan tentang kemaha kuasaan Allah-Tuhan Yang Maha Esa, maka sebagai asumsi juga dapat disimpulkan tentang adanya paham kedaulatan Tuhan yang dianut dalam UUD 1945. Penegasan tentang Ketuhanan Yang Maha Esa, sebagai dasar negara yang terdapat dalam Pasal 29 ayat (1) UUD 1945 juga dapat diasumsikan sebagai dasar dianutnya kedaulatan Tuhan. Di samping ketiga ajaran kedaulatan tersebut, UUD 1945 juga memiliki kemungkinan menganut ajaran kedaulatan negara. Secara historis, kedaulatan negara sesungguhnya kelanjutan dari kedaulatan raja, padahal UUD 1945 secara tegas tidak mengikutinya, karena itu ajaran kedaulatan negara juga tidak dianut. Akan tetapi, secara substansi, kemungkinan dianutnya ajaran kedaulatan negara juga ada, sebagai misal, adanya rumusan dalam Pasal 33 UUD 1945.

Perubahan rumusan pasal 1 ayat (2) UUD 1945 berimplikasi pada struktur dan

${ }^{6}$ Jimly Asshiddiqie, Gagasan Kedaulatan Rakyat dalam Konstitusi dan Pelaksanaannya di Indonesia, PT. Ichtiar Baru Van Hoeve, Jakarta, 1994, hlm. 10.

7 Soewoto Mulyosudarmo, Op.cit., hlm.4. 
mekanisme lembaga negara sebagai pelaksana kedaulatan dalam ketatanegaraan; karena itu perlu dirumuskan implikasi perubahan rumusan Pasal 1 ayat (2) UUD 1945 terhadap sistem ketatanegaraan, dalam hal ini lembaga negara pelaksana kedaulatan. Penelitian ini perlu pula mengetahui implementasi konsepsi kedaulatan dalam ketatanegaraan atau pada lembaga negara pelaksana kedaulatan, yang terpancar dalam tugas dan wewenang lembagalembaga negara tersebut.

Berdasarkan uraian di atas, penelitian ini perlu dilakukan untuk menemukan jawaban secara konsepsional melalui kajian yang mendalam dan komprehensif dalam suatu tulisan ilmiah berbentuk disertasi. Sepanjang pengetahuan penulis, belum pernah ada penelitian yang mendalam dan komprehensif menjawab berbagai pertanyaan di atas. Kalaupun ada, masih sebatas tulisan insidental para ahli yang memuat salah satu atau beberapa aspek saja. Penelitian tentang gagasan dan konsep kedaulatan rakyat, demikian pula dengan makna Pasal 1 ayat (2) UUD 1945 memang pernah dilakukan oleh peneliti terdahulu dalam bentuk disertasi, ${ }^{8}$ namun itu dilakukan sebelum Perubahan III UUD 1945. Padahal Pasal 1 ayat (2) UUD 1945 (Perubahan III) yang menyebutkan: "Kedaulatan berada di tangan rakyat dan dilaksanakan menurut Undang-Undang Dasar", mengubah secara mendasar konsep ketatanegaraan Indonesia.

${ }^{8}$ Beberapa penelitian disertasi terdahulu, antara lain adalah: Gagasan Kedaulatan Rakyat Dalam Konstitusi dan Pelaksanaannya di Indonesia (Jimly Asshiddiqie, Th. 1992), Makna Pasal 1 ayat (2) UUD 1945 dan Penerapannya Dalam MPR Masa Kerja 1972-1992 (Agung Aryanto, Th. 1996), Konsepsi Kedaulatan Rakyat Menurut UUD 45 Dan Implementasinya Dalam Praktek Ketatanegaraan Studi Tentang MPR Sebagai Pelaku Kedaulatan Rakyat Sepenuhnya, (Dahlan Thaib, Th. 2000).
Berdasarkan latar belakang penelitian ini dan dalam hubungannya dengan judul penelitian ini, maka dikemukakan identifikasi masalah, sebagai berikut: a. Bagaimanakah konsepsi kedaulatan menurut UUD 1945 (Pasal 1 ayat (2)); b. Bagaimanakah implikasi perubahan rumusan Pasal 1 ayat (2) UUD 1945 terhadap lembaga negara pelaksana kedaulatan?; dan c. Bagaimanakah implementasi konsepsi kedaulatan menurut Pasal 1 ayat (2) UUD 1945 pada lembaga negara pelaksana kedaulatan? Tujuan penelitian ini adalah untuk menemukan jawaban terhadap tiga pertanyaan pokok tersebut.

\section{METODE PENELITIAN}

Berdasarkan objek, permasalahan dan tujuan penelitian ini, maka metode penelitian yang tepat dipergunakan ialah metode penelitian hukum normatif. Sebagaimana dikemukakan oleh Soerjono Soekanto dan Sri Mamudji, ${ }^{9}$ penelitian hukum yang dilakukan dengan cara meneliti bahan pustaka atau data sekunder belaka dapat dinamakan penelitian hukum normatif atau penelitian hukum kepustakaan. Penelitian hukum normatif atau kepustakaan mencakup: penelitian terhadap asas-asas hukum; penelitian terhadap sistematik hukum; penelitian terhadap taraf sinkronisasi vertikal dan horisontal; perbandingan hukum; dan sejarah hukum.

Pendekatan yang dipergunakan dalam penelitian ini adalah pendekatan filsafat hukum, perbandingan hukum, dan sejarah pembentukan hukum. Sesuai dengan objek dan metode pendekatan dalam penelitian ini, maka penelitian ini menjadikan bahan pustaka sebagai bahan utama penelitian. Oleh karena penelitian ini menggunakan data sekunder

${ }^{9}$ Soerjono Soekanto dan Sri Mamudji, Penelitian Hukum Normatif, Rajawali, Jakarta, cetakan ke-3, 1990, hlm 15. 
sebagai objek penelitian, maka data yang didapat yang meliputi bahan hukum primer, sekunder, dan tertier dianalisis secara kualitatif dengan menggunakan instrumen teori atau konsep sebagaimana diuraikan dalam kerangka pemikiran untuk menjawab permasalahan dalam penelitian ini. Analisis kualitatif dipaparkan dalam bentuk deskriptip.

\section{HASIL DAN PEMBAHASAN}

\section{A. Konsepsi Kedaulatan Dalam Pelbagai UUD yang Sedang dan Pernah Berlaku di Indonesia.}

\section{Konsepsi Kedaulatan Menurut UUD 1945 (naskah asli)}

Berdasarkan analisis terhadap UUD 1945, yaitu pembukaan dan batang tubuhnya, dapat disimpulkan bahwa UUD 1945 menganut teori kedaulatan Tuhan, teori kedaulatan negara, teori kedaulatan rakyat, dan teori kedaulatan hukum. Meskipun lahirnya teori kedaulatan negara merupakan kelanjutan dari teori kedaulatan raja, padahal UUD 1945 menolak teori kedaulatan raja, karena itu dapat dikatakan bahwa UUD 1945 juga tidak menganut teori kedaulatan negara. Akan tetapi, jika dilihat secara substansi, bahwa teori kedaulatan negara mempersoalkan bahwa negaralah yang berdaulat sebagaimana diatur dalam Pasal 33, maka UUD 1945 dapat dipandang menganut kedaulatan negara, di samping juga kedaulatan lainnya.

Di lihat dari sistematika kedaulatan, dengan berdasarkan pada pemahaman bahwa kehadiran berbagai kedaulatan (Tuhan, negara, hukum) yang diatur dalam UUD, tidak lain karena kehendak rakyat yang berdaulat yang mengakuinya, karena itu dapat juga diartikan bahwa kedaulatan rakyat yang dijiwai oleh Ketuhanan Yang Maha Esa (kedaulatan Tuhan), menurut hukum (kedaulatan hukum), untuk kepentingan bangsa dan negara.

\section{Konsepsi Kedaulatan Menurut Konstitusi RIS 1949.}

Berdasarkan penelitian dan analisis yang telah dilakukan terhadap pertanyaan, siapakah yang berdaulat meunurut Konstitusi RIS 1949? Atau dengan kata lain Konstitusi RIS 1949 menganut teori kedaulatan apa? Dapat disimpulkan bahwa Konstitusi RIS 1949 menganut teori kedaulatan Tuhan, teori kedaulatan Rakyat dan teori kedaulatan hukum. Meskipun secara teoritis ketiga teori kedaulatan yang dianut oleh Konstitusi RIS 1949 terpisah satu dengan lainnya sehingga menimbulkan kesan bahwa ada pertentangan antara kedaulatan yang satu dengan kedaulatan lainnya, sesungguhnya dapat disinergikan dengan pemahaman bahwa dalam negara RIS, kedaulatan hukum dengan instrumen prinsipprinsip negara hukum sedapat mungkin hukum harus dapat menjelmakan hakikat kehendak dari rakyat Indonesia yang percaya dan bertakwa pada Tuhan Yang Maha Esa.

\section{Konsepsi Kedaulatan Menurut UUDS 1950}

Berdasarkan analisis yang telah dilakukan dapat disimpulkan bahwa UUDS 1950 menganut beberapa teori kedaulatan, ialah kedaulatan Tuhan, kedaulatan negara, kedaulatan rakyat dan juga kedaulatan hukum. Hubungan antara keempat kedaulatan tersebut dapat dirumuskan dengan sederhana bahwa, kedaulatan rakyat harus mencerminkan kedaulatan Tuhan, dan berdasar kedaulatan hukum untuk kejayaan bangsa dan negara. Kempat kedaulatan itu jika ditelusuri berdasarkan prósesnya, pada dasarnya berangkat dari kedalatan rakyat.

\section{Konsepsi Kedaulatan Menurut UUD 1945 (perubahan)}

Berdasarkan uraian yang telah dikemukakan pada bagian ini, dapat disimpulkan bahwa UUD 1945 setelah 
perubahan menganut konsepsi kedaulatan Tuhan, kedauatan negara, kedaulatan rakyat, dan kedaulatan hukum. Akan tetapi secara prosedural, sesungguhnya UUD 1945 (perubahan) menganut kedaulatan rakyat.

B. Implikasi Perubahan Rumusan Pasal 1 ayat (2) UUD 1945 Terhadap Ketatanegaraan.

Perubahan rumusan Pasal 1 ayat (2) UUD 1945 berimplikasi terhadap ketatanegaraan. Bagir Manan, ${ }^{10}$ mengemukakan bahwa rumusan baru Pasal 1 ayat (2) UUD 1945 dimaksudkan: pertama, menegaskan kedaulatan akan selalu di tangan rakyat, sebab selama ini ada semacam tafsir bahwa MPR yang memegang kedaulatan rakyat (penjelasan Pasal 3). Rakyat seolah-olah mengalihkan kedaulatan kepada MPR, sehingga rakyat pun tergantung pada kemauan MPR. Kedua, kedaulatan rakyat dilaksanakan menurut UUD juga dimaksudkan bahwa MPR bukan satu-satunya yang melaksanakan kedaulatan rakyat, kedaulatan rakyat dilaksanakan juga oleh lembaga negara yang lain. Ketentuan ini juga bermaksud bahwa kekuasaan semua alat kelengkapan negara terbatas, yaitu dibatasi oleh UUD.

Jimly Asshiddiqie" ${ }^{11}$ dalam bukunya Konsolidasi Naskah UUD 1945 Setelah Perubahan keempat, mengemukakan bahwa dengan perubahan ini (perubahan rumusan Pasal 1 ayat (2) UUD 1945), MPR tidak lagi memiliki kedudukan yang eksklusif sebagai satu-satunya instansi pelaku atau pelaksana kedaulatan rakyat, MPR tidak lagi sepenuhnya melakukan kedaulatan rakyat karena di samping MPR ada pula lembaga-lembaga negara lain yang juga merupakan pelaku atau

\footnotetext{
${ }^{10}$ Bagir Manan, Perkembangan UUD 1945, Fak. Hukum UII Press, Yogyakarta, 2004, hlm. 52-53.

${ }^{11}$ Jimly Asshiddiqie, Konsolidasi ..., Op.cit., hlm.
}

pelaksana kedaulatan rakyat.

Berdasarkan pendapat Bagir Manan, Jimly Asshiddiqie, dan KK, dapat dikemukakan pokok-pokok yang menjadi maksud dari rumusan Pasal 1 ayat (2) UUD 1945 (perubahan) sebagai implikasi dari perubahan pasal ini, yaitu: (i) merupakan penegasan bahwa kedaulatan rakyat tetap pada rakyat, tidak beralih pada lembaga negara sebagaimana kadang ditafsirkan seolah-olah kedaulatan rakyat itu beralih pada MPR; (ii), MPR hanya salah satu pelaksana kedaulatan rakyat, di samping lembaga negara lainnya; (iii) hubungan kelembagaan negara tidak lagi secara vertikal yang berpuncak pada MPR, melainkan secara horisontal (sejajar). (iv) semua kekuasaan alat lembaga negara dibatasi oleh UUD, dengan kata lain menganut supremasi hukum.

\section{Implementasi Konsepsi Kedaulatan Dalam Ketatanegaraan.}

Implementasi konsepsi kedaulatan dalam ketatanegaraan diarahkan pada kedudukan, tugas dan wewenang lembaga-lembaga negara yang masuk kategori state organ atau lembaga utama negara/lembaga negara lapis pertama, yaitu DPR, MPR, DPD, Preside, MA, MK, dan BPK. Karena itu, UU yang secara khusus mengatur lembaga negara terseut menjadi objek kajian.

Implementasi konsepsi kedaulatan terkait dengan perubahan rumusan Pasal 1 ayat (2) UUD 1945 dalam undang-undang terhadap MPR dan DPR dalam hal ini UU RI No. 22 Tahun 2003 tentang Susunan dan Kedudukan MPR, DPR, DPD, dan DPRD, secara umum telah sesuai. Akan tetapi semangat perubahan rumusan pasal itu belum sejalan terhadap DPD. Penyebabnya, bukan saja karena UU tidak mengimplementasikannya, melainkan kebe- 
radaan DPD dalam Pasal 22D UUD 1945 memang cacat secara substansial.

Implementasi konsepsi kedaulatan terkait dengan perubahan rumusan Pasal 1 ayat (2) UUD 1945 dalam undang-undang terhadap lembaga negara Presiden. Karena belum ada UU yang secara khusus mengatur tentang lembaga kepresidenan, maka keberadaan Presiden dapat ditelaah dari kekuasaannya/ kewenangannya dalam berbagai UU. Menurut Bagir Manan, ${ }^{12}$ kekuasaan Presiden RI dalam arti luas meliputi (i) kekuasaan penyelenggaraan pemerintahan; (ii) kekuasaan di bidang perundang-undangan; (iii) kekuasaan di bidang yustisial; dan (iv) kekuasaan Presiden dalam hubungan luar negeri. Secara umum, keuasaan Presiden dalam berbagai UU yang terkait dengan kekuasaannya tersebut telah sejalan dengan semangat perubahan Pasal 1 ayat (2) UUD 1945.

Implementasi konsepsi kedaulatan terkait dengan perubahan rumusan Pasal 1 ayat (2) UUD 1945 terhadap MA sebagaimana diatur dalam UU No. 5 Tahun 2004 Tentang Perubahan Atas UU No. 14 Tahun 1985 Tentang Mahkamah Agung

Undang-Undang No. 24 Tahun 2004 Tentang Kekuasaan Kehakiman, telah sejalan dengan semangat perubahan rumusan Pasal 1 ayat (2) UUD 1945. Adapun implementasinya terhadap MK, sebagaimana diatur dalam UU No. 24 Tahun 2003 Tentang Mahkamah Konstitusi, juga secara umum telah sejalan, kecuali dalam hal pembatasan kurun waktu UU yang dapat diuji hanya pada UU yang diundangkan setelah perubahan UUD 1945, namun kemudian dicabut oleh MK

12 Bagir Manan, Lembaga Kepresidenan, Diterbitkan Atas Kerja sama Pusat Studi Hukum UII dengan Gama Media, Yogyakarta, 1999, hal. 121166.
Implementasi konsepsi kedaulatan terkait dengan perubahan rumusan Pasal 1 ayat (2) UUD 1945 dalam undang-undang terhadap BPK dalam UU No. 15 tahun 2006 tentang BPK secara umum juga telah sesuai.

\section{PENUTUP}

\section{Kesimpulan}

Bertitik tolak dari identifikasi masalah serta penelitian dan pembahasan yang telah dilakukan, selanjutnya dikemukakan kesimpulan:

1. Bahwa baik dalam Konstitusi RIS 1949 dan UUDS 1950 demikian pula dalam UUD 1945 sebelum dan sesudah perubahan, konsepsi kedaulatan yang dianut adalah kedaulatan Tuhan, kedaulatan negara, kedaulatan rakyat dan kedaulatan hukum.

2. Perubahan rumusan Pasal 1 ayat (2) UUD 1945 berimplikasi terhadap lembaga negara pelaksana kedaulatan, yaitu jika sebelum perubahan, MPR dipandang sebagai satu-satunya pelaksana kedaulatan rakyat, maka setelah perubahan MPR hanya salah satu pelaksana kedaulatan rakyat di samping lembaga negara lainnya, seperti DPR, DPD, Presiden, MA, MK, dan BPK.

3. Adapun implementasi konsepsi kedaulatan menurut Pasal 1 ayat (2) UUD 1945 dalam undang-undang yang mengatur perihal lembaga negara utama pelaksana kedaulatan adalah sebagai berikut: Bahwa dalam UU No. 22 tahun 2003 tentang Susunan dan Kedudukan MPR, DPR, DPD, dan DPRD, UU No. 4 tahun 2004 tentang Kekuasaan Kehakiman, UU No. 14 tahun 1985 tentang MA, dan UU No. 5 tahun 2004 tentang Perubahan atas UU No. 14 tahun 1985 tentang MA, UU No. 15 
tahun 2006 tentang BPK, secaru garis besar telah sesuai, meskipun masih perlu penyempurnaan.

\section{Saran-saran}

1. Perlu dilakukan penyempurnaan terhadap UU yang terkait DPD sehingga semakin konsisten dengan konsepsi kedaulatan dalam UUD 1945, terkait perubahan Pasal 1 ayat (2) UUD 1945.

2. Perlu ada penelitian lanjutan yang secara khusus meneliti prinsip-prinsip kedaulatan Tuhan dalam UUD 1945.

$-000-$

\section{DAFTAR PUSTAKA}

Bagir Manan, Lembaga Kepresidenan, Diterbitkan Atas Kerja sama Pusat Studi Hukum UII dengan Gama Media, Yogyakarta, 1999

-, Perkembangan UUD 1945, FH UII Press, Yogyakarta, 2004.

Feith, Herbert, The Declaine of Constitutional Democracy in Indonesia, Cornell University Press, fourth printing, Ithaca and London, 1973.

Hazairin, Demokrasi Pancasila, Bina Aksara, Jakarta, 1985.

Ismail Suny, Pembagian Kekuasaan Negara, Aksara Baru, Jakarta, 1982.

Jimly Asshiddiqie, Gagasan Kedaulatan Rakyat dalam Konstitusi dan Pelaksanaannya di Indonesia, P.T. Ichtiar Baru Van Hoeve, Jakarta, 1994.

, Format Kelembagaan Negara dan Pergeseran Kekuasaan dalam UUD 1945, FH UII PRESS, Yogyakarta, 2004.

Kahim, George Mc. T., Nationalism and Revolution in Indonesia, seven printing, Cornell University Press, Ithaca, New York, 1986.

Kelsen, Hans, Pure Theory of Law, Max Knight: university of California Press, 1978.

Kranenburg, Ilmu Negara Umum (penerjemah: Sabaroedin), Pradnya Paramita, Jakarta, 1975.
Miriam Budiardjo, Dasar-dasar Ilmu Politik, Gramedia, Jakarta, 1989.

- Aneka Pemikiran Tentang Kuasa dan Wibawa, Sinar Harapan, Jakarta, 1986.

Mohammad Hatta, Kedaulatan Rakyat, Kementerian Penerangan, Jakarta, 1946. , Kumpulan Pidato I,II,III (1942-1949, 1951-1979,1945-1948), Disusus Oleh: I. Wangsa Widjaja \& Meutia F. Swasono, PT. Toko Gunung Agung Tbk. Devisi Penerbit, Jakarta, 2002.

Mueller, Dennis C., Constitutional Democraty, Oxford University Press, 1996.

Muhammad Yamin, Proklamasi dan Konstitusi Republik Indonesia, Penerbit Djambatan, Jakarta, 1954.

Nagel, Jack H., The Descriptive Analysis of Power, New Haven, Yale University Press, 1975.

Sri Edi Swasono \& Fauzie Ridjal (ed.), Mohammad Hatta: Beberapa Pokok Pikiran, UI-Press, Jakarta, 1992.

Sri Soemantri, Prosedur dan Sistem Perubahan Konstitusi, Alumni, Bandung, 1987.

Strong, C.F., Modern Political Constitutions, Sidgwick \& Jackson, London, 1966.

Soerjono Soekanto \& Sri Mamudji, Penelitian Hukum Normatif -suatu tinjauan singkat, Rajawali Press, Jakarta, 1990.

Soewoto Mulyosudarmo, Pembaharuan Ketatanegaraan Melalui Perubahan Konstitusi, Asosiasi Pengajar HTN-HAN Jawa Timur dan In-TRANS, Malang, 2004.

Wheare, K.C., Modern Constitutions, Butler \& Tanner, Ltd, London, 1952.

\section{Makalah, Orasi Ilmiah, Jurnal:}

Anwar, Keberadaan BPK dalam Penciptaan Clean Governance, Makalah disajikan dalam SEMILOKA dan MUSDA Asosiasi Pengajar HTN dan HAN Jawa Timur di Tretes, 22-24 Oktober 2000.

Bagir Manan Pembaharuan Lembaga-Lembaga Negara dalam UUD 1945-Baru, Makalah yang disampaikan sebagai ceramah dihadapan civitas akademika Universitas Sam Ratulangi, Manado, Januari 2007 
